\title{
THE FEATURES OF THE INTERNATIONAL LEGAL REGULATION OF OBLIGATIONS ARISING FROM UNFAIR COMPETITION
}

\author{
Adel I. Abdullin ${ }^{1}$ \\ Dinar A. Valeev ${ }^{2}$ \\ Gulshan G. Bodurova ${ }^{3}$
}

\begin{abstract}
The paper draws attention to the peculiarities of the regulation of obligations arising as a result of unfair competition within the framework of international legal documents. The authors emphasize the fact that, unlike other types of non-contractual crossborder relations, obligations arising from unfair competition often have a public character. According to the authors, this particular feature is the determining factor in the conflict of law and substantive regulation of these obligations. The paper notes that the formation and development of the conflict of law and substantive regulation of obligations in relation to Industrial Property, the Agreement on Trade-related Aspects of Intellectual Property Rights, and Regulation (EU) No 864/2007 of the European Parliament and the Council dated July 11, 2007."On the law to be applied to non-contractual obligations" ("Rome II"). Nonetheless, a reasonable conclusion is that the international legal instruments governing the obligations that have arisen as a result of unfair competition include substantive law, aimed at preventing unfair competition. As a rule, these are norms aimed at finding particular ways to solve the problem of conflict of obligations arising as a result of unfair competition.
\end{abstract} the unfair competition were significantly influenced by the norms of international treaties. In particular, they include the

Keywords: unfair competition; international legal agreements; business Paris Convention for the Protection of

\footnotetext{
${ }^{1}$ Kazan Federal University. e-mail: valeevdinarlaw@gmail.com. Tel.: 89372804747

${ }^{2}$ Kazan Federal University. e-mail: valeevdinarlaw@gmail.com. Tel.: 89372804747

${ }^{3}$ Kazan Federal University. e-mail: valeevdinarlaw @ gmail.com. Tel.: 89372804747
} 
entities; market; conflict regulation; substantive regulation.

\section{Introduction}

In modern conditions, the development of market relations is an indicator of the level of development of a state. Moreover, today it is relevant to talk about cross-border market relations when business entities operate not only in the territory of any particular state but enter new markets, overcoming state borders. In these respects, competition as a form of confrontation for market leadership is the normal functioning of a civilized market. Both private individuals (consumers, entrepreneurs) and the state are interested in developing competitive relations. But, unfortunately, it is necessary to observe the facts of unfair competitive relations on the part of some business entities aimed at causing certain losses to other business entities. In almost all countries, attempts are being made at the legislative level to limit unfair competition in order to ensure free economic activity for market entities. Various approaches to the legal regulation of this institution, which are reflected not only in national legal systems but also in international legal acts, give rise to a special interest in obligations arising from unfair competition in the field of private law relations.

\section{Methods}

The paper uses both general scientific methods of scientific knowledge and particular scientific methods. Among them, one can single out analysis, synthesis, comparison, and formal legal and technical legal methods.

\section{Results And Discussion}

The features of obligations arising as a result of unfair competition and complicated by a foreign element are examined and disclosed. The distinguishing features of the conflict of law regulation concerning obligations arising from unfair competition, which are mainly inherent in the norms of national law, and the features of substantive regulation which are inherent in the international legal regulation of this issue are identified. It was revealed that international legal regulation of obligations arising as a result of unfair competition has a significant impact on the formation of national mechanisms for regulating the issue under consideration. 


\section{Summary}

As is known, obligations arising from the unfair competition are categorized as non-contractual relations. The latter arise on the basis of certain actions and not a concluded contract between business entities.

It should be emphasized that the distinctive feature of obligations arising as a result of unfair competition and other types of non-contractual relations should be a peculiar combination of private and public principles. Indeed, states are interested in developing stable market relations, which is why one cannot but agree with Sh.T. Tagaynazarov, who wrote that active state intervention in these areas and relations is necessary in order to prevent abuse and enhance legitimate behaviour $[1,64]$.

In this regard, public law regulation of relations arising as a result of unfair competition, which is aimed at protecting the interests of a state and society, in no way diminishes the significance of civil law regulation of the obligations under consideration aimed at protecting the interests of directly participants of market relations [2, 446]. Considering the special interconnection and interweaving of public law and civil law regulation of relations arising as a result of unfair competition, we consider it necessary to characterize and separate their private-public character as a separate sign.

Like all civil law relations, including competition, obligations arising from the unfair competition are based on the general principles of the Civil Code of the Republic of Tajikistan. In particular, Article 10 of the Civil Code of the Republic establishes that it is prohibited to use civil rights in order to limit competition, as well as abuse of one's dominant position in the market.

Article 1228, the Civil Code of the Republic of Tajikistan establishes the conflict of laws regulation of obligations arising from unfair competition, which states that the law of the country which market is affected by such a competition applies as applicable law unless otherwise provided by the legislative act or the substance of the obligation. Moreover, the suppression of unfair competition is ensured by bringing to civil law, criminal and administrative liability, as well as to liability directly provided for by the Law of the Republic of Tajikistan "On Competition and 
Limiting Monopolistic Activities in Commodity Markets" of 2006.

From the above analysis, it follows that the main feature of conflict regulation of relations arising as a result of unfair competition is the combination and peculiar weaving of conflict of law and substantive regulation. As N.N. Voznesensky noted quite rightly on this issue, this alignment of cases greatly complicates the conflict problem, while at the same time raising special interest in it $[3,4]$.

In this regard, we consider it necessary to point out the particularities of international legal regulation of obligations arising as a result of unfair competition. The latter has a significant impact on the legal nature of unfair competition in the framework of private international law.

For both the Russian Federation and the Republic of Tajikistan, the Paris Convention for the Protection of Industrial Property played a significant role in developing a definition of the essence of unfair competition. As N.G. Vilkova believes, despite the fact that in Russian legislation the concept of unfair competition is contained in the Law "On Competition and the Limitation of
Monopolistic Activities in Commodity Markets" (Article 10) dated March 22, 1991, not all business entities are well aware of the categories of actions that constitute unfair competition [4, 117]. In this regard, it seems necessary to appeal to other forms of consolidating the issue under consideration, in particular, the Convention on the Protection of Industrial Property of 1883.

What is the connection between such various definitions as industrial property and unfair competitive relations? In fact, the relationship between them is direct, because, as you know, the objects of industrial property are such institutions as a trademark, service mark, company name. The latter, in turn, may become the object of unauthorized use of some business entities, which, according to the above law, qualifies as a form of unfair competition. This circumstance explains the fact that the suppression of unfair competition is included in the list of industrial property protection objects specified in clause 2 of article 1 of the Paris Convention [5]. The norms of the convention define in the general sense the essence of unfair competition, and also embody the conflict of laws 
regulation of the mentioned legal relations. Interest in this regard is caused by the norms of Article 10.bis obliging the countries of the union to provide citizens of countries with effective protection against unfair competition, and to provide, according to Article 10.ter, citizens of other countries legal means to suppress these actions.

Thus, it is clear that indirect conflict regulation of obligations arising as a result of unfair competition at the international level under the Paris Convention for the Protection of Industrial Property. The Convention lays down rules aimed at suppressing unfair competition. It obliges the participating countries to apply the provisions of the security and guarantee nature in order to suppress the occurrence of unfair competition when persons belonging to the citizenship of another state participate in such legal relations.

N.N. Voznesensky, in turn, believes that containing certain substantive rules in the field of protection against unfair competition, which establish the rights and obligations of private law entities, the Paris Convention does not fully regulate legal relations in the field of protection against unfair competition [3, 21 ]. It is difficult to agree with his opinion, since the norms of the Paris Convention are aimed, first of all, at protecting industrial property objects. Putting the suppression of unfair competition on a par with industrial property, the convention provides for a sufficient amount of legal protection, which is of interest from both the substantive and the conflict of law points of view.

The next document which is governing unfair competition at the international level in the light of the protection of the intellectual property is the 1994 Agreement on Trade-Related Aspects of Intellectual Property Rights (TRIPS). This Convention, like the Paris Convention, does not aim to comprehensively regulate issues of protection against unfair competition, but by virtue of the objects under consideration, it also touches on issues of protection against unfair competition, which takes place in the aspect of certain legal relations. In the light of the conflict of laws regulation, this Agreement, like the Paris Convention, is of interest from the point of view of imposing obligations on member states to take certain actions to curb unfair competitive relations in the 
light of the protection of intellectual property.

In light of the collision of law regulation concerning obligations arising from unfair competition, the most notable is the law of the European Union, in particular, the provisions of the Rome II Regulation, which governs, in addition to other types of non-contractual crossborder obligations, also obligations arising from unfair competition. And it is no mere chance that thanks to its elaboration, the rules of the Regulation, as indicated by Kh.D. Pirtskhalava, acquired the importance of general norms in relation to national norms, which act as subsidiary $[6,100]$. P. Stone notes that the norms established in the Regulation are quite stable [7, 377], which, of course, testifies to their significance. The significance of the rules of the Regulation is also written by John Ahern and William Binchy, which indicate various kinds of conflict bindings and methods of their application [8, 90]. Of course, it is necessary to emphasize that, despite different points of view on the applicability of the Rules of the Regulation to non-contractual crossborder obligations that take place immediately after its adoption [9, 1], with the adoption of the Regulation, noncontractual cross-border obligations, including those resulting from unfair competition, got a "second wind" and reached a new level of development.

It is important to note that in certain circumstances, when several markets are affected by the restriction of competition, the plaintiff is given the opportunity to choose the law of the country of the court as applicable law, but provided that the market of this state is also covered by the restriction of unfair competition, in which the claim is actually filed (paragraph $3 \mathrm{~b}$ of article 6 of the Regulation) [10]. There is a certain manifestation of signs of autonomy of the will. Indeed, unlike other laws, this rule represents an original approach, since, taking into account a specific, special case, it gives the injured party the right to choose the law of the country where the court takes place as applicable law, but, as the document itself emphasizes, not always, but only if certain conditions exist. And it is not surprising that following this rule, the Regulation in clause 4 of the article in question denies the use of autonomy of will to the extent that the use of this 
institution is allowed in relation to other types of non-contractual cross-border obligations.

In fact, the Regulation deals with the conflict of laws regulation of two definitions: unfair competition and actions restricting free competition. For example, paragraph 17, Article 4 of the Law of the Russian Federation "On the Protection of Competition" lists the general features of this definition without giving a definition of the term "restriction of competition". From the meaning inherent in this article, it follows that in contrast to obligations arising from unfair competition, the obligations arising from the restriction of competition, are usually associated with abuse by an entity of its dominant position in the market. And the latter, in turn, can lead to a significant restriction of competition. In the legal literature, abuse of a dominant position in the market is understood as the improper use of subjective property rights, used to impose unfair conditions on other participants in market relations.

According to the law, actions restricting free competition do not apply to forms of unfair competition. Hence it should be assumed that if the restriction

\section{3}

on competition in the general sense is aimed at suppressing monopolistic activity, and by its nature is incompatible with unfair competition, then the signs of restriction of competition specified in the law, i.e. actions inherently unacceptable in the light of the functioning of freemarket relations should be attributed to unfair competition. In this regard, we fully support the point of view by N.N. Voznesensky that the dividing line between these definitions is not drawn either in law or in practice $[3,46]$. This circumstance, according to the author, is connected with the goal that pursues competition law - the protection of competition both in the interests of business entities and in the interests of society as a whole. Therefore, it is not surprising that the legislation of some countries does not draw a line between the categories under consideration and puts them on a par. In particular, in relation to the regulation of relations of private international law, Article 117 of the Romanian Law No. 105 of 1992 establishes that the right of a state in the market of which there are harmful consequences extends to claims for damages based on allegations of unfair competition or other actions, and which 
entail illegal restrictions on free competition. As one can see, both unfair competition and actions restricting competition are subject to conflict regulation $[11,513]$. In this case, the legislator includes actions constituting the essence of competition restriction as part of unfair competitive relations in the aspect of private regulation of these definitions. According to German jurisprudence, actions restricting competition are also considered, in certain circumstances, as forms of unfair competition. [12, 16]. The same approach is enshrined in Art.6 of Rome II Regulation "Unfair competition and actions which restricting free competition". Of interest in this aspect is the innovation enshrined in the civil legislation of the Russian Federation, which enshrines the conflict of law regulation of both unfair competition and restriction of competition (Article 1222, "The Law Governing Obligations arising from Unfair Competition and Due to Restriction of Competition"). But we believe that in the light of the expansion of conflict of bindings, it is more advisable to talk specifically about actions that restrict free competition. In this context, it seems necessary to correlate both general and private unfair competition and actions restricting free competition.

\section{Conclusions}

So, to summarize the above, and exploring the features of international legal regulation of obligations arising from unfair competition, we note that given all the developing and complicated social economic relations that extend far beyond the borders of a particular state, national law and international law should also to expand the sphere of its influence and cover these relations with its regulation.

Currently, the norms of international treaties in most cases are aimed at suppressing unfair competition; in particular, they oblige states to carry out certain actions with the aim of suppressing unfair competitive relations.

\section{Acknowledgements}

The work is performed according to the Russian Government Program of Competitive Growth of Kazan Federal University. 
Periódico do Núcleo de Estudos e Pesquisas sobre Gênero e Direito

Centro de Ciências Jurídicas - Universidade Federal da Paraíba V. 8 - No 06 - Ano 2019 - Special Edition ISSN | 2179-7137 | http://periodicos.ufpb.br/ojs2/index.php/ged/index

\section{References}

Tagaynazarov Sh.T. Civil status of a person in the USSR and improvement of civil legislation // Strengthening socialist legality and improving legislation. Collection of scientific works. Dushanbe, 1984. P.64.

Commentary on the third part of the Civil Code of the Russian Federation. / edited by T.E. Abova. M.: Yurayt Publishing House, 2004.Vol.3. P.446.

Voznesensky N.N. Obligations due to unfair competition in international private law: a thesis for the degree of Candidate of Legal Sciences: 12.00.03 / Voznesensky Nikolai Nikolaevich. M., 2008. P.4.

Vilkova N. G. Regulation of unfair competition in French law // Economy and Law. 1995. N 4 (219).P.117.

Convention for the Protection of Industrial Property of 03.20.1883 (edition of 02.10.1979) // (www.consultant.ru/document/com) (access date 05.25.2019).
Pirtskhalava H.D. Legal regulation of non-contractual cross-border obligations (for example, the Russian Federation and Spain): a thesis for the degree of candidate of legal sciences. M., 2013. P.100

Stone P. EU Private International Law, 2 nd ed., Elgar Pub., 2010.P.377.

Ahern John and Binchy William. The Rome II Regulation on the Law Applicable to Non-Contractual Obligations. Martinus Nijhoff, 2009. P. 90.

Dickinson Andrew. The Rome II Regulation. The Law Applicable to NonContractual Obligations. Oxford University Press, 2010. P.1.

Regulation (EU) No 864/2007 of the European Parliament and of the Council dated 11 July 2007 "On the Law Governing Non-Contractual

Obligations" ("Rome II") // (http://eulaw.edu.ru/documents/legislati on/collision/vnedogovomoe.htm) (accessed 25.12. 2019). 


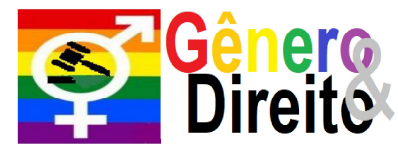

Periódico do Núcleo de Estudos e Pesquisas sobre Gênero e Direito

Centro de Ciências Jurídicas - Universidade Federal da Paraíba

V. 8 - No 06 - Ano 2019 - Special Edition

ISSN | 2179-7137 | http://periodicos.ufpb.br/ojs2/index.php/ged/index

Private International Law: Foreign

Legislation / Preface by A.L. Makovsky;

compilator and scientific editor A.N.

Zhiltsov, A.I. Muranov. M. : "Statute",

2000. S.513.

Zimenkova O.N. Legal regulation of the

fight against unfair competition in the

EEC and in the member countries of the community: an abstract of a thesis for the degree of candidate of legal sciences. M., 1984. P. 16 